\title{
内部障害のリハビリテーション：理論と実際*1
}

\author{
上月 正博*2
}

\section{Visceral Rehabilitation : Theory and Practice ${ }^{* 1}$}

\begin{abstract}
Masahiro KoHzuKI ${ }^{* 2}$
Abstract : Visceral impairment (VI), including cardiac, renal, pulmonary, hepatic, intestinal, urinary and rectal, AIDS is a worldwide public health problem. Recently, the number of patients with VI dramatically increased, reaching $30 \%$ of the total population of disabled patients in Japan in 2006 , which corresponds to $60 \%$ of patients with limb impairment. Visceral rehabilitation (VR) is a coordinated, multifaceted intervention designed to optimize a patient's physical, psychological, and social functioning, in addition to stabilizing, slowing, or even reversing the progression of the disease, thereby reducing morbidity and mortality. VR includes five major components : exercise training, diet \& fluid management, medication \& medical surveillance, education, psychological \& vocational counseling. VR is a feasible, effective (Class I, evidence label A) and safe secondary prevention strategy following VI, and offers a promising model for a new field of rehabilitation. Medical science basically aims to "Adding Years to Life" by increasing life expectancy. Rehabilitation generally aims to "Adding Life to Years" by helping patients with impairment achieve, and use, their full physical, mental and social potential. However, recent growing evidence suggests that rehabilitation for patients with VI not only improves exercise performance and quality of life, but also increases survival. Therefore, modern comprehensive rehabilitation for patients with visceral impairment does not simply aim to "Adding Life to Years" but "Adding Life to Years and Years to Life", which is a new rehabilitation concept. Urgent efforts should be made to increase the implementation rate of VR. (Jpn J Rehabil Med 2013; $50 ： 212-224$ )
\end{abstract}

Key words : 内部障害（visceral impairment），肝臟リハビリテーション (hepatic rehabilitation), 運動 (exercise)，腎㵴リハビリテーション (renal rehabilitation)，心臟リハビリ テーション (cardiac rehabilitation)

\section{はじめに}

\section{わが国は予想以上の速いペースで超高齢社会を}

迎えた。内部障害者数は急増し，2006 年にはつ いに身体障害者総数の $30 \%$ を突破し，肢体不自 由者数と比較してその $60 \%$ 以上にも達した。ま た，内部障害の中での障害の重複化，特に心臟機
能障害, 呼吸器機能障害, 腎臓機能障害の重複が 目立ってきた。これまでの医療は寿命の延長 (adding years to life)，リハビリテーション（以 下，リハ）は日常生活活動（ADL）や生活の質 (quality of life：QOL) の改善 (adding life to years) を主に目指してきたが，内部障害リハは生活の質 の改善と寿命の延長 (adding life to years and years to life）を達成できる医療である1,2).

2012 年 10 月 2 日受稿

*1 本稿は第 49 回日本リハビリテーション医学会学術集会教育講演（2012 年 6 月 1 日, 福岡) をまとめたものである.

*2 東北大学大学院医学系研究科障害科学専攻 機能医科学講座内部障害学分野/ = 980-8574 宮城県仙台市青葉区星陵町 1-1 Department of Internal Medicine and Rehabilitation Science, Tohoku University Graduate School of Medicine E-mail : kohzuki@med.tohoku.ac.jp 
内部障害リハの対象疾患もますます拡大し, 診 療報酬改定においても普及のためのさまざまな配 慮がなされてきている，運動療法やリハに取り組 む各学会も規模を拡大し, 会員数や発表演題数を 着実に増やしている。このような状況から内部障 害リハが，いまやすべてのリハ関連職種が精通す べき基本領域になったといえる。

本稿では, 内部障害リハの最近の進歩を踏ま え, 心臓機能障害, 呼吸器機能障害, 腎臓機能障 害，肝臟機能障害を中心にその理論と実際を述べ る.

\section{内部障害の定義}

わが国の身体障害者福祉法では，身体障害は， 視覚障害, 聴覚・言語障害, 肢体不自由, 内部障 害の 4 つに分類される。ささらに，内部障害を，心 臓機能障害, 腎臓機能障害, 肝臓機能障害, 呼吸 機能障害, 膀胱 - 直腸機能障害, 小腸機能障害, ヒト免疫不全ウイルスによる免疫機能障害の 7 つ と規定している3゙.

\section{内部障害の疫学}

わが国の身体障害者について, 約 5 年ごとに厚 生労働省により実態調查が行われている。報告さ れている最新のデー夕（2006 年調査）によると， 全国の 18 歳以上の身体障害者数（在宅）は 348 万 3000 人と推計され, 2001 年の調査と比較して $7.3 \%$ 増加していた（図 1, 表 1) ${ }^{4}$. 障害者全体に 対する内部障害者の占める割合は年々増加してお り，2006 年には $30 \%$ を突破した。特に 2001 年か ら 2006 年の 5 年間での増加率は, 視覚障害, 聴 覚・言語障害, 肢体不自由ががほぼ横ばいである のに対して，内部障害は $26.0 \%$ と非常に高いこと は特筆に值する (図 1, 表 1$)^{4)}$.

2006 年の内部障害者数は 107 万人であるが, その内訳は心臓機能障害が 59 万 5000 人と過半数 を占め，腎臓機能障害が 23 万 4000 人，膀胱また は直腸機能障害が 13 万 5000 人, 呼吸器機能障害 が 9 万 7000 人，小腸機能障害が 8000 人，ヒト免

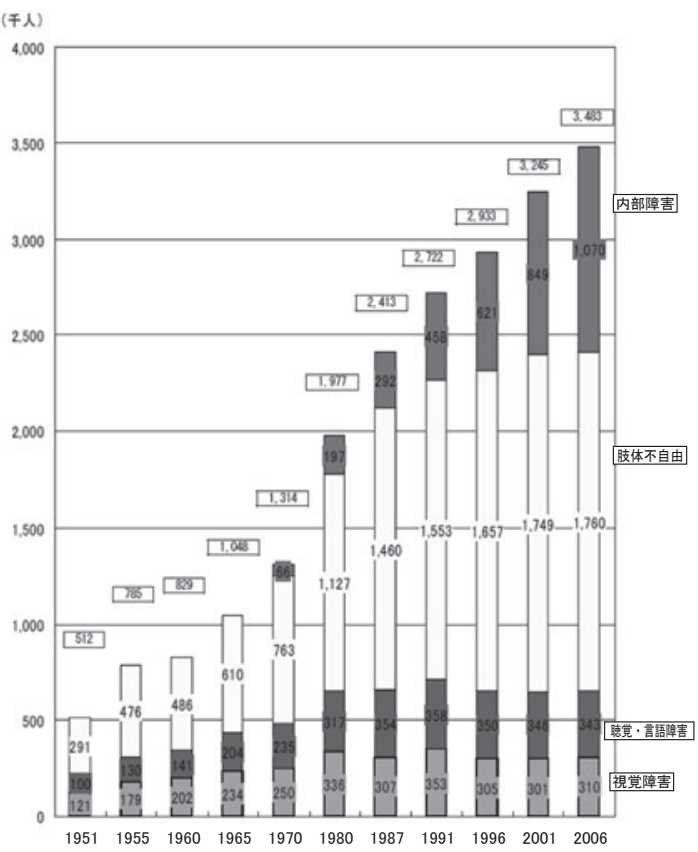

図 1 障害の種類別にみた身体障害者数の推移（文献 4 より引用)

疫不全ウイルスによる免疫機能障害が 1000 人で ある $(\text { 表 } 2)^{4)}$. 内部障害者の年齢階級別の分布を 見ると，高齢者が占める割合が非常に高く ${ }^{4)}$, 近 年，わが国での人口の超高齢化の加速が内部障害 者の増加の原因の 1 つと考えられる。ささらにこれ らの障害の危険因子となり得る糖尿病患者や脂質 異常症患者などの増加も顕著であり, 今後も内部 障害者増加は続くことが予想される。また，2006 年の調査では, 複数の障害を有する重複障害者が $77.1 \%$ と急増し, その中でも内部障害と肢体不自 由の重複障害が最多であった ${ }^{4)}$ 。これも超高齢化 の加速や動脈硬化性疾患患者の増加によるものと 考えられよう。

また，臨床的には内部障害を有しながら，法律 的には身体障害の等級としては軽いため敢えて申 請していない人々まで加えれば, 内部障害者数は さらに増えることになる。一方，障害により生活 維持に支障が生じた場合に年金が支給される「障 害年金」の支給対象疾患には呼吸器疾患, 心疾 患，腎疾患，肝疾患のほかに，高血圧，糖尿病， 悪性新生物なども含まれている。今後はこのよう 
上月正博

表 1 障害の種類別にみた身体障害者数の推移（文献 4 より引用）

\begin{tabular}{|c|c|c|c|c|c|c|}
\hline 年次 & 総数 & 視覚障害 & 聴覚·言語障害 & 肢体不自由 & 内部障害 & （再掲）重複障害 \\
\hline \multicolumn{7}{|c|}{ 推計数（単位：千人） } \\
\hline 1951 年 & 512 & 121 & 100 & 291 & - & - \\
\hline 1955 年 & 785 & 179 & 130 & 476 & - & - \\
\hline 1960 年 & 829 & 202 & 141 & 486 & - & 44 \\
\hline 1965 年 & 1,048 & 234 & 204 & 610 & - & 215 \\
\hline 1970 年 & 1,314 & 250 & 235 & 763 & 66 & 121 \\
\hline 1980 年 & 1,977 & 336 & 317 & 1,127 & 197 & 150 \\
\hline 1987 年 & 2,413 & 307 & 354 & 1,460 & 292 & 156 \\
\hline 1991 年 & 2,722 & 353 & 358 & 1,553 & 458 & 121 \\
\hline 1996 年 & 2,933 & 305 & 350 & 1,657 & 621 & 179 \\
\hline 2001 年 & 3,245 & 301 & 346 & 1,749 & 849 & 175 \\
\hline 2006 年 & 3,483 & 310 & 343 & 1,760 & 1,070 & 310 \\
\hline \multicolumn{7}{|c|}{ 構成比（単位：\%） } \\
\hline 1951 年 & 100.0 & 23.6 & 19.5 & 56.8 & - & - \\
\hline 1955 年 & 100.0 & 22.8 & 16.6 & 60.6 & - & - \\
\hline 1960 年 & 100.0 & 24.4 & 17.0 & 58.6 & - & 5.3 \\
\hline 1965 年 & 100.0 & 22.3 & 19.5 & 58.2 & - & 20.5 \\
\hline 1970 年 & 100.0 & 19.0 & 17.9 & 58.1 & 5.0 & 9.2 \\
\hline 1980 年 & 100.0 & 17.0 & 16.0 & 57.0 & 10.0 & 7.6 \\
\hline 1987 年 & 100.0 & 12.7 & 14.7 & 60.5 & 12.1 & 6.5 \\
\hline 1991 年 & 100.0 & 13.0 & 13.2 & 57.1 & 16.8 & 4.4 \\
\hline 1996 年 & 100.0 & 10.4 & 11.9 & 56.5 & 21.2 & 6.1 \\
\hline 2001 年 & 100.0 & 9.3 & 10.7 & 53.9 & 26.2 & 5.4 \\
\hline 2006 年 & 100.0 & 8.9 & 9.8 & 50.5 & 30.7 & 8.9 \\
\hline \multicolumn{7}{|c|}{ 対前回比（単位：\%） } \\
\hline 1951 年 & - & - & - & - & - & - \\
\hline 1955 年 & 153.3 & 147.9 & 130.0 & 163.6 & - & - \\
\hline 1960 年 & 105.6 & 112.8 & 108.5 & 102.1 & - & - \\
\hline 1965 年 & 126.4 & 115.8 & 144.7 & 125.5 & - & 488.6 \\
\hline 1970 年 & 125.4 & 106.8 & 115.2 & 125.1 & - & 56.3 \\
\hline 1980 年 & 150.5 & 134.4 & 134.9 & 147.7 & 298.5 & 124.0 \\
\hline 1987 年 & 122.1 & 91.4 & 111.7 & 129.5 & 148.2 & 104.0 \\
\hline 1991 年 & 112.8 & 115.0 & 101.1 & 106.4 & 156.8 & 77.6 \\
\hline 1996 年 & 107.8 & 86.4 & 97.8 & 106.7 & 135.6 & 147.9 \\
\hline 2001 年 & 110.6 & 98.7 & 98.9 & 105.6 & 136.7 & 97.8 \\
\hline 2006 年 & 107.3 & 103.0 & 99.1 & 100.6 & 126.0 & 177.1 \\
\hline
\end{tabular}

な疾患に由来する身体障害も内部障害の対象範囲 として広げていくべきであると考えられる゙3.

\section{内部障害リハの構成要素とゴール}

内部障害リハは科学的なリハ処方に基づく理 学・運動療法, 作業療法, 言語聴覚療法に加え て，きちんとした薬物療法・食事療法・患者教育・ カウンセリングをセットにして行われることで威 力が倍增する。このようなリ八を包括的リ八と呼
び，内部障害リハを行うには包括的リハの知識が 欠かせない。

内部障害リハのゴールは単に在宅生活における $\mathrm{ADL}$ の自立，QOL の改善，復職にのみあるので はない.内部障害リハでは，それらに加えて， 1）運動耐容能の増加，2）動脈硬化の改善，3）心 血管危険因子の是正，4）生命予後の改善などの めざましい効果も示されており，原疾患の再発防 止, 生命予後の改善, 動脈硬化性疾患の予防・治 療，動脈硬化巣そのものの改善など，攻めの医療 
内部障害のリハビリテーション：理論と実際

表 2 障害の種類別にみた身体障害者数（文献 4 より引用）

\begin{tabular}{|c|c|c|c|}
\hline & 2001 年 & 2006 年 & 対前回比 \\
\hline 総 数 & $3,245(100.0)$ & $3,483(100.0)$ & $107.3 \%$ \\
\hline 視覚障害 & $301(9.3)$ & $310(8.9)$ & $103.0 \%$ \\
\hline 聴覚·言語障害 & $346(10.7)$ & $343(9.8)$ & $99.1 \%$ \\
\hline 聴賞障害 & $305(9.4)$ & 276( & $90.5 \%$ \\
\hline 平衡機能障害 & $7(0.2)$ & $25(0.7)$ & $357.1 \%$ \\
\hline 音声・言語そしゃく機能障害 & $34(1.0)$ & $42(1.2)$ & $123.5 \%$ \\
\hline 肢体不自由 & $1,749(53.9)$ & $1,760(50.5)$ & $100.6 \%$ \\
\hline 上肢切断 & $98(3.0)$ & $82(2.4)$ & $83.7 \%$ \\
\hline 上肢機能障害 & $479(14.8)$ & $444(12.7)$ & $92.7 \%$ \\
\hline 下肢切断 & $49(1.5)$ & $60(1.7)$ & $122.4 \%$ \\
\hline 下肢機能障害 & $563(17.4)$ & $627(18.0)$ & $111.4 \%$ \\
\hline 体幹機能障害 & $167(5.1)$ & $153(4.4)$ & $91.6 \%$ \\
\hline 脳原性全身性運動機能障害 & $60(1.8)$ & $58(1.7)$ & $96.7 \%$ \\
\hline $\begin{array}{l}\text { 全身性運動機能障害 } \\
\text { (多肢及び体幹) }\end{array}$ & $333(10.3)$ & $337(9.7)$ & $101.2 \%$ \\
\hline 内部障害 & $849(26.2)$ & $1,070(30.7)$ & $126.0 \%$ \\
\hline 心臓機能障害 & $463(14.3)$ & $595(17.1)$ & $128.5 \%$ \\
\hline 呼吸器機能障害 & $89(2.7)$ & $97(2.8)$ & $109.0 \%$ \\
\hline じん臓機能障害 & $202(6.2)$ & 234( & $115.8 \%$ \\
\hline ぼうこう・直腸機能障害 & $91(2.8)$ & 135( & $148.4 \%$ \\
\hline 小腸機能障害 & $3(0.1)$ & $8(0.2)$ & $266.7 \%$ \\
\hline $\begin{array}{l}\text { ヒト免疫不全ウイルス } \\
\text { による免疫機能障害 }\end{array}$ & $2(0.1)$ & $1(0.1)$ & $50.0 \%$ \\
\hline （再掲）重複障害 & $175(5.4)$ & $310(8.9)$ & $177.1 \%$ \\
\hline
\end{tabular}

としての役割も担っている3.

\section{心臟機能障害}

心臓リハのゴールは，脳卒中リハのように単に 在宅生活や復職ではなく, 心血管疾患の再発防 止，生命予後の延長を含むものである5)。すなわ ち，心臓リ八は長期的で包括的なプログラムであ る。このプログラムは, 個々の患者の心疾患に基 づく身体的・精神的影響をできるだけ軽減し，突 然死や再梗塞のリスクを是正し，症状を調整し， 動脈硬化の過程を抑制あるいは逆転させ，心理社 会的ならびに職業的な状況を改善することを目的 とする ${ }^{6}$.

心藏リハにより，(1)運動耐容能の増加，(2)冠動 脈硬化・冠循環の改善，(3)冠危険因子の是正，(4)
生命予後の改善, (5) QOL の改善などのめざまし い効果が示されている $(\text { 表 } 3)^{7)}$ 。わが国では日本 心臓リハ学会・日本循環器学会を中心として「心 血管疾患におけるリハビリテーションに関するガ イドライン (2007 年改訂版)」が作成され，心臓 リハの実際とその効果が詳細にまとめられ7), 2012 年の改訂に筆者も関与している。

心臟リハは，心筋梗塞や心不全を発症して入院 してから自宅へ退院するまでの急性期心臓りハ, 社会復帰を目標とした回復期心臓リハ，社会復帰 以後生涯を通じて行われる維持期心臓リハに分け られる。心臓リハのエビデンスは急性期心臓リハ によってではなく，その後の社会復帰を目標とし た数力月にわたる回復期心臓リハによって達成さ れる．米国心臓学会のガイドラインでは心筋梗塞 患者の長期生命予後を改善する方法でエビデンス 
レベル最高ランクのクラス I ・エビデンス A に挙

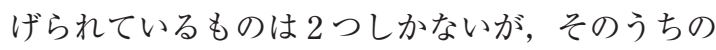

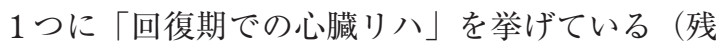
りの 1 つはスタチン (脂質異常症治療薬 $))^{8)}$.

最近，わが国では診療報酬制度での心大血管疾 患リハの適応疾患が拡大された。すなわち，心臓 リハの有効性が認められている循環器疾患は, 心 筋梗塞以外にも, 狭心症, 冠動脈バイパス術後, 心臓弁膜症術後，大動脈瘤手術後，心不全，心臓 移植後，末梢動脈疾患などがありいずれも診療報 酬に収載された ${ }^{9)}$ 。これらの疾患に対する心臓り 八のエビデンスも欧米ではクラス I ・エビデンス A に挙げられている。すなわち，回復期心臓リハ は循環器疾患にとって「必須かつ最高レベルの医 療」として広く認知されたわけである。

また，わが国の 2010 年と 2012 年の診療報酬改 定では心臓リハの施設基準も緩和された。すなわ
ち，(1)心大血管疾患リハ（ I ）の施設基準におい て，(24 時間 365 日）常時勤務することとされて いた循環器科又は心臓血管外科の医師を，心臓血 管疾患リハを実施している時間帯においては常時 勤務することに緩和された。(2)心大血管疾患リハ に専従する理学療法士又は看護師について，心大 血管疾患リハを行わない時間帯においては他の疾 患別リハ等に従事可能とすることになった。(3)心 大血管疾患リハに専用の機能訓練室については, それぞれの施設基準を満たせば，他の疾患別リハ に専用の機能訓練室と同一の部屋とできることに なった. その際，当該リハと他の疾患別リハ及び 集団コミュニケーション療法を同一の従事者が行 う場合，心大血管疾患リハに実際に従事した時間 20 分を 1 単位としてみなした上で，他の疾患別 リハ等の実施単位数を足した值が，従事者 1 人に つき 1 日 18 単位を標準とし, 週 108 単位までと

表 3 心疾患における運動療法の身体効果（文献 7 より引用）

\begin{tabular}{|c|c|c|}
\hline 項 目 & 内 & エビデンスのランク \\
\hline \multirow[t]{2}{*}{ 運動耐容能 } & 最高酸素摂取量増加 & A \\
\hline & 嫌気性代謝閾值増加 & $\mathrm{A}$ \\
\hline \multirow[t]{2}{*}{ 症 状 } & 心筋虚血䦔值の上昇による狭心症発作の軽減 & $\mathrm{A}$ \\
\hline & 同一労作時の心不全症状の軽減 & A \\
\hline 呼 吸 & 最大下同一負荷強度での換気量減少 & A \\
\hline \multirow[t]{2}{*}{ 心 臟 } & 最大下同一負荷強度での心拍数減少 & A \\
\hline & 最大下同一負荷強度での心仕事量（二重積）減少 & A \\
\hline \multirow[t]{3}{*}{ 冠動脈 } & 冠狭窄病変の進展抑制，軽度の退縮 & $\mathrm{B}$ \\
\hline & 心筋灌流の改善 & $\mathrm{B}$ \\
\hline & 冠動脈血管内皮機能の改善 & $\mathrm{B}$ \\
\hline 中心循環 & 最大動静脈酸素較差の増大 & $\mathrm{B}$ \\
\hline \multirow[t]{2}{*}{ 末梢循環 } & 安静時, 運動時の総末梢血管抵抗減少 & $\mathrm{B}$ \\
\hline & 未梢動脈血管内皮機能の改善 & $\mathrm{B}$ \\
\hline \multirow[t]{4}{*}{ 骨格筋 } & ミトコンドリアの増加 & A \\
\hline & 骨格筋酸化酵素活性の増大 & $\mathrm{A}$ \\
\hline & 骨格筋毛細管密度の増加 & A \\
\hline & II 型から I 型への筋線維型の変換 & A \\
\hline 冠危険因子 & 高血圧, 脂質代謝, 糖代謝の改善 & $\mathrm{B}$ \\
\hline \multirow[t]{2}{*}{ 自律神経 } & 交感神経緊張の低下 & A \\
\hline & 圧受容体反射感受性の改善 & B \\
\hline \multirow[t]{2}{*}{ 血 液 } & 血小板凝集能低下 & B \\
\hline & 血液凝固能低下 & $\mathrm{B}$ \\
\hline \multirow[t]{3}{*}{ 予 後 } & 冠動脈性事故発生率の減少 & A \\
\hline & 心不全増悪による入院の減少 & $\mathrm{B}(\mathrm{CAD})$ \\
\hline & 生命予後の改善 ～～～～ & $\mathrm{B}(\mathrm{CAD})$ \\
\hline
\end{tabular}

$\mathrm{A}$ ：証拠が十分であるもの, B：論文の質は高いが論文数が十分でないもの. $\mathrm{CAD}$ : 冠動脈疾患 
することになった（4)入院中にリハを行った場合 は, 治療開始日から 14 日に限り, 早期リ八加算 として，1単位につき 45 点加算された。 (5)適切 な運動処方のための検査として，心肺運動負荷試 験施行時の連続呼気ガス分析加算として 100 点加 算された。つまり，エビデンスレベルの高い心蔵 リハは，採算の面でも行いやすくなり，その普及 に弾みがつく可能性が出てきたことになる ${ }^{9,10)}$.

心臓リハはその活躍の領域を拡大し, 心血管疾 患の再発予防や一次予防にも寄与している。それ を象徴するものとして, 海外の心臓リハ学会や機 関誌の名前に “prevention (予防)”を加えるとこ ろが出てきた。すなわち, 欧州では European Association for Cardiovascular Prevention \& Rehabilitation（EACPR）ができ，その機関誌として European Journal of Cardiovascular Prevention and Rehabilitation（EJCPR）ができた。 また，米国で は, American Association of Cardiovascular and Pulmonary Rehabilitation (AACVPR) があり，そ の機関誌の名称は Journal of Cardiopulmonary Rehabilitation (JCR) から, Journal of Cardiopulmonary Rehabilitation and Prevention (JCRP) に改 名された11).

わが国の心臓リハの学会活動の活発化と学会認 定心臓リ八指導士制度の確立もみのがせない。す なわち，わが国では心蔵り八研究会を前身として 日本心臓リハ学会が創設され, 心藏リハの臨床・ 研究を牽引している. 2013 年 1 月現在で総会員 数 8870 名（医師 2093 名, 看護師 1837 名, 理学 療法士 3739 名, 臨床検査技師 269 名, 健康運動 指導士 167 名，作業療法士 201 名）とこの領域の 組織としては世界最大を誇っており, 年次集会参 加者も 3000 名以上を数える。また, 現在学会認 定の約 2000 名以上の心臓リ八指導士が存在する. 筆者は 2013 年の日本心臓リ八学会学術集会長で あるが，「重複障害時代における心臓リハの役割」 というテーマを掲げ，日本心臓リ八学会と日本リ 八医学会などとの共同セッションを設けて, わが 国のリハ医学・医療のさらなる発展をめざしてい る.

\section{呼吸器機能障害}

呼吸リハは,「呼吸器の病気によって生じた障 害を持つ患者に対して, 可能な限り機能を回復, 維持させ，これにより，患者自身が自立できるこ とを継続的に支援していくための医療である」12). 呼吸リハの研究は主に慢性閉塞性肺疾患 (chronic obstructive pulmonary disease : COPD）でなされ ており，近年その有効性も明らかになってきてい る. 2007 年改定 ACCP/AACVPR ガイドライン ${ }^{12)}$ や 2007 年改定 GOLD ガイドライン ${ }^{13)}$ では, リハ は COPD に対する有効な治療として高く評価さ れ, COPD に対する非薬物療法の最初に行うべき ものとして位置づけられている（表 4)。また， わが国でも日本呼吸器学会の「COPD 診断と治療 のためのガイドライン第 3 版」で, 呼吸リハは非 薬物療法の最初に位置付けられている (図 2) ${ }^{14)}$. 日本呼吸ケア・リ八学会を中心として，「呼吸リ ハビリテーションマニュアルー運動療法一」 $(2003 \text { 年, } 2012 \text { 年改訂 })^{15)}$,「呼吸リハビリテー ションマニュアル一患者教育の考え方と実践一」 $\left(2007\right.$ 年 ${ }^{16)}$ が刊行された。 日本リ八医学会も筆者 が委員長として查読協力を行っている，また，診 療報酬も2006 年から呼吸器リハ料として収載さ れており, 今後のさらなる普及発展が期待され る.

COPD 患者に対する呼吸リハの必須要素として は歩行筋の運動トレーニングプログラムが推奨さ れている. 呼吸リハの効果として, (1)運動耐容能 の増加, (2)呼吸困難の改善, (3)健康関連 QOL の 改善, (4)入院日数など医療資源利用率の減少など が明らかになった。最近は間質性肺炎に対する運 動療法の有効性も明らかになってきており, 運動 耐容能の改善, 息切れの減少, QOLの改善効果 が示されている．COPD 患者に対する呼吸リハの エビデンスは, 心蔵リハや脳卒中のリハのエビデ ンスにもはや遜色ないレベルにまで高まってい る. 最近は COPD 以外の呼吸器疾患, 例えば間 質性肺炎などでも呼吸リハの有効性が示されてき ている. 
表 42007 年改定 ACCP/AACVPR ガイドラインから引用した呼吸リハの効果（文献 13 より引用）

\begin{tabular}{|c|c|c|}
\hline \multirow{2}{*}{$\begin{array}{l}\text { エビデンス } \\
\text { レベル }\end{array}$} & \multicolumn{2}{|c|}{ 推奨レベル } \\
\hline & 1（高い） & 2（低い） \\
\hline A（強い） & 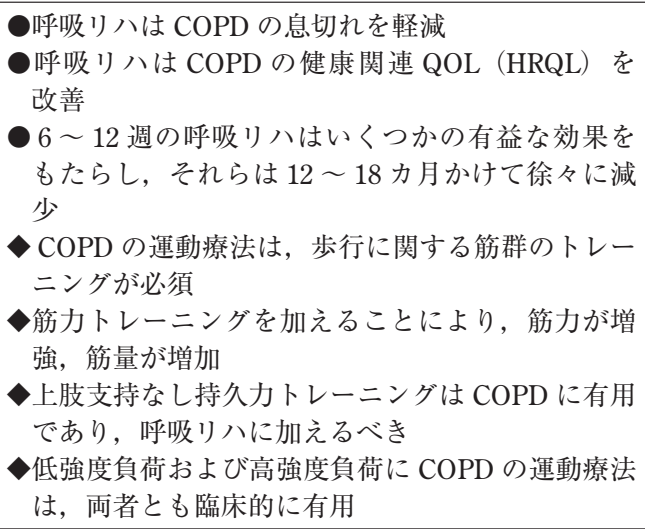 & \\
\hline B（中等度） & 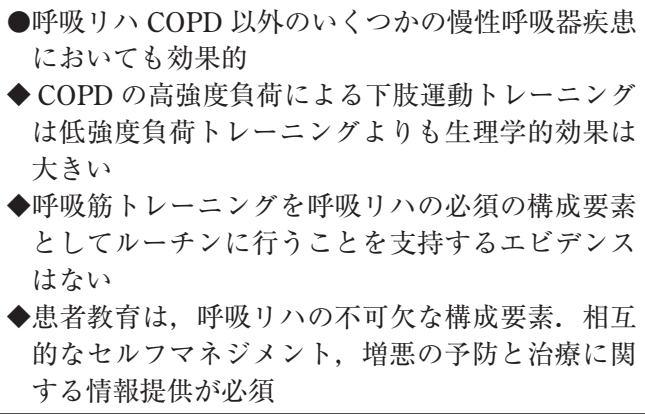 & $\begin{array}{l}\text { O呼吸リハは COPD の入院日数や医療資源の利用を } \\
\text { 減少 } \\
\text { COPDに対する包括的呼吸リハは心理社会的効果 } \\
\text { をもたらす } \\
\text { 選択された重症 COPD の運動トレーニングに } \\
\text { NPPVを併用すると, ある程度の相加的な効果が } \\
\text { 得られる }\end{array}$ \\
\hline C（弱い） & $\begin{array}{l}\text { HRQL 等いくつかの呼吸リハの効果は, } 12 \text { ～} 18 \\
\text { カ月の時点でも対照群を超えて維持される } \\
\text { 高度の運動誘発性低酸素血症をきたす患者には呼 } \\
\text { 吸リハ中は酸素投与をすべき }\end{array}$ & 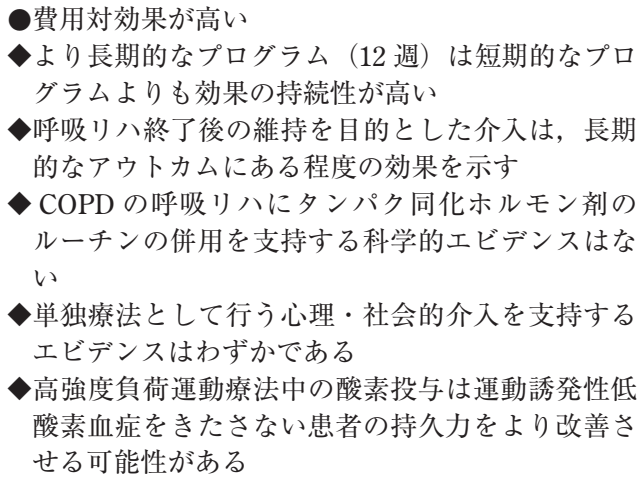 \\
\hline
\end{tabular}

1）COPD に対する生命予後改善効果は, エビデンスが不十分，効果として推奨はできない.

2）COPD の呼吸リハにおいて，ルーチンの栄養補給療法併用を支持する科学的エビデンスは不十分，推奨はできない.

3）エビデンスに基づく推奨はできないが，臨床の現場および専門家の見解は心理・社会的介入を包括呼吸リハの構成要 素として支持している.

4）エビデンスに基づく推奨はできないが，臨床の現場および専門家の見解は，COPD 以外の慢性呼吸器疾患患者への呼 吸リハは，COPD と非COPDの共通の治療計画に，疾患別，個別の治療計画を加えたものとすることを示唆している.

：呼吸リハの効果に関するエビデンス，・：手技，介入方法に関するエビデンス

一方，わが国で盛んに行われている口すぼめ呼 吸や腹式呼吸などの呼吸理学療法の COPD に対 する有効性は明らかとは言えず，「呼吸筋トレー
ニングを呼吸リハの必須要素としてルーチン使用 することを裏づける科学的エビデンスはない」と されている ${ }^{13)}$. COPD 患者 (肺が過膨張し横隔膜 


\section{安定期COPDの管理}

COPD断と治粫のためのガイドライン 第3版（日本呼吸器学会 2009）

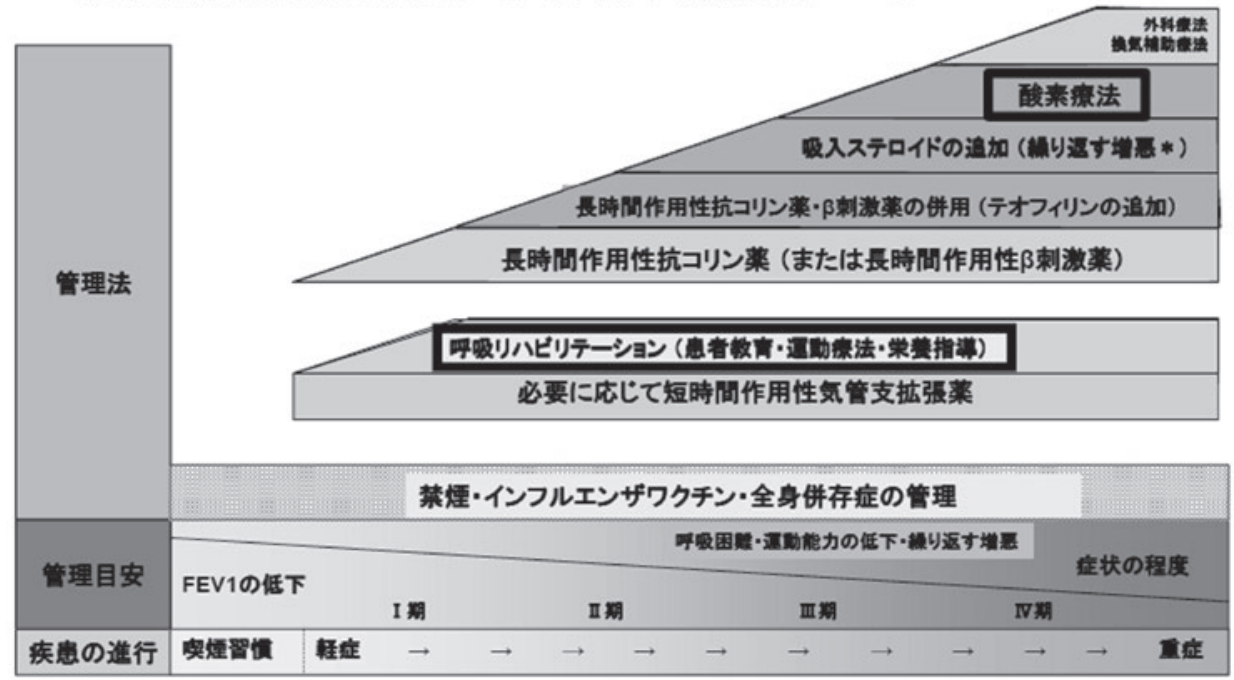

図 2 COPD の各病期における治療法（文献 14 より引用）

がすでに低位の状態になっている）では腹式呼吸 そのものを行うことが困難である．腹式呼吸を指 導すると, 一回換気量や分時換気量が増加し, $\mathrm{PaO}_{2}$ が上昇, $\mathrm{PaCO}_{2}$ が低下するが，その代償と して呼吸仕事量が増加し, 結果として呼吸困難が 増悪し，呼吸効率が悪化するために，高度に進行 したCOPD 患者に対しては望ましくない。

呼吸障害のリハで重要なことは,リハが運動療 法だけで成り立つのではなく，きちんとした薬物 療法・食事療法・患者教育・カウンセリングなど をセットにした「包括的リハ」として行われるこ とでその威力が倍増することである．著者らは呼 吸リハにより肺移植が 1 年以上回避できた例も経 験している ${ }^{17)}$ 。呼吸リハのゴールは，患者の ADL を拡大するだけでなく，不安を軽減し，QOLを 向上させるものでなければならない。今後とも患 者の生活機能やライフスタイルを把握し，生活面 での工夫や環境の改善にも配慮する全人的なアプ ローチが必要である、今後は, 呼吸理学療法や栄 養管理の有効性のエビデンスの有無などもさらに 詳細に検討されるべきである。

われわれは，2005 年に宮城県内在住の在宅酸
素療法患者にアンケート対象調査を行った結果, 呼吸リハの経験がある患者は $42 \%$ と全国調査と 同様の結果であった。また，呼吸リハの説明を受 けた患者の $87 \%$ は呼吸リ八経験がある一方，呼 吸リハ経験のない患者の $91 \%$ は呼吸リハの説明 を受けていなかった，すなわち，患者がリ八に参 加するか否かは，主治医がその説明をするか否か に左右されることが明らかになった ${ }^{18)}$. 主治医や リ八科医による呼吸リ八の積極的な勧誘が必要で ある。

\section{腎臓機能障害}

2011 年末のわが国の慢性透析患者数は 30 万人 を突破し，国民 400 人に 1 人の割合にまで高まっ た ${ }^{19)}$. 超高齢社会を反映して, 透析患者も年々高 齢化し，2011 年末の透析人口全体の平均年齢は 65.8 歳, 2011 年新規導入透析患者の平均年齢は 67.3 歳である ${ }^{19)}$.

透析患者では，腎性貧血，尿毒症性低栄養，骨 格筋減少 - 筋力低下, 骨格筋機能異常, 運動耐容 量の低下，易疲労感，活動量減少，QOL 低下が 
など認められる。長期間にわたって透析を行って いると，心不全や低血圧などの合併症が発生し， それが透析患者の QOLを一層低下させてしまう. さらに, 透析合併症や超高齢化に伴う多疾患や透 析合併症による重複障害により安静を保つこと で，運動耐容能はさらに低下し，廃用症候群に 陥ってしまう。透析患者の運動耐容能は心不全患 者や COPD 患者のものと同レベルまで低下して いる ${ }^{20)}$. 運動耐容能の低い透析患者や運動をしな い透析患者では生命予後が悪いことが明らかに なっている ${ }^{21)}$ 。さらに，透析患者が運動を行わな いことは, 低栄養・左室肥大と同程度に生命予後 に影響することが指摘されている DOPPS 研究では, 定期的な運動習慣のある透析 患者は，非運動患者に比較して明らかに生命予後 が良いこと, 週当たりの運動回数が多いほど生命 予後が良い22).さらに，定期的な運動習慣をもつ 透析患者の割合が多い施設ほど，施設当たりの患 者死亡率が低い22).

運動療法は, 透析患者に対して運動耐容能改 善, 低栄養・炎症複合症候群改善, タンパク質異 化抑制，QOL 改善などをもたらすことが明らか にされている $\left(\right.$ 表 5 ${ }^{23)}$.「透析患者の心血管疾患 に対する K/DOQI 臨床ガイドライン 2005 年版」 では,「医療関係者は透析患者の運動機能評価と 運動の奨励を積極的に行う必要がある」と明記し てある (表 6 ${ }^{24)}$ 。

腎藏リハは, 腎臓疾患や透析医療に基づく身体 的・精神的影響を軽減させ, 症状を調整し, 生命 予後を改善し，心理社会的ならびに職業的な状況 を改善することを目的として，運動療法，食事療 法と水分管理, 薬物療法, 教育, 精神 - 心理的开 ポートなどを行う，長期にわたる包括的なプログ ラムによるリハである25).

透析患者に対する運動療法の標準的なメニュー は, 非透析日に週 $3 \sim 4$ 回, 1 回に $30 \sim 60$ 分の 歩行, エルゴメーターなどの中強度（最大の 60\%未満）有酸素運動が中心となる. 低強度の筋 力増強訓練を加える場合もある. 通常は運動施設 か自宅で行う。また，運動前後のストレッチン グ, 関節可動域維持訓練, 筋力増強訓練を追加す
ることが望ましい.

最近は, 透析の最中に下肢エルゴメーターなど の運動療法を行う施設も増加してきた。透析中に 運動を行うことでタンパク同化が促進され，また リンなどの老廃物の透析除去効率が高まり, 1 回 の透析時間を 4 時間から 5 時間にしたのと同程度 の効果があるとされる。また, 週 3 回の透析の際 に運動療法を行ってしまうことで，改めて透析以 外の時間帯に長い運動時間を設定しなくてよい. 退屈な透析時間をどう過ごすかに悩んでいる透析 患者にとっては，非常な朗報であるといえる．

さらに, 透析には至らない保存的腎不全の患者 においても, 適度な運動が腎臓機能には悪影響を 及ぼさずに，むしろ運動耐容能や QOL の向上, 糖・脂質代謝の改善などのメリットをもたらす可 能性があるという報告があり，腎臓機能障害患者 の活動を過度に制限すべきではないことが示唆さ れている，運動による心血管疾患やメタボリック シンドロームの予防効果は, 中等度の強度で 1 日 30 分の運動でも認められることから, CKD ガイ ドラインでは,「運動疲労を起こさない程度の運 動（5 METs 前後）が安定した CKD を悪化させ るという根拠はなく, 合併症などの身体状況が許 す限り, 定期的施行が推奨される」とされてい $ろ^{26)}$. 透析には至らない保存的腎不全の各種動物 モデルでは，運動はむしろ腎臓保護に働くことが 筆者の教室を中心に報告されている27 32).

運動療法のみでさまざまな好ましい身体効果を もたらすことはすでに述べたとおりである。しか し水分, 塩分, タンパク質制限などの栄養療法 (食事療法), 降圧薬などの薬物療法, 生活指導, 精神的ケアなどの要素も重要である。このことは 同じ内部障害に分類される心臓機能障害や呼吸器 機能障害のリハでも同様であり, 運動療法は, き ちんとした薬物療法・食事療法・患者教育（自己 管理や病状悪化の予防と治療に関する教育) ・精 神的ケアなどをセットにしたメニューとして行わ れることでその威力が倍増する。

腎臓リハの必要性に関しては, 従来のリハ医学 や腎臓病・透析医学の教科書にはほとんど触れら れることがなく, 医療者・患者双方の腎蔵リハの 
表 5 透析患者の心血管疾患に対する K/DOQI 臨床ガイドライン（文献 23 より引用）

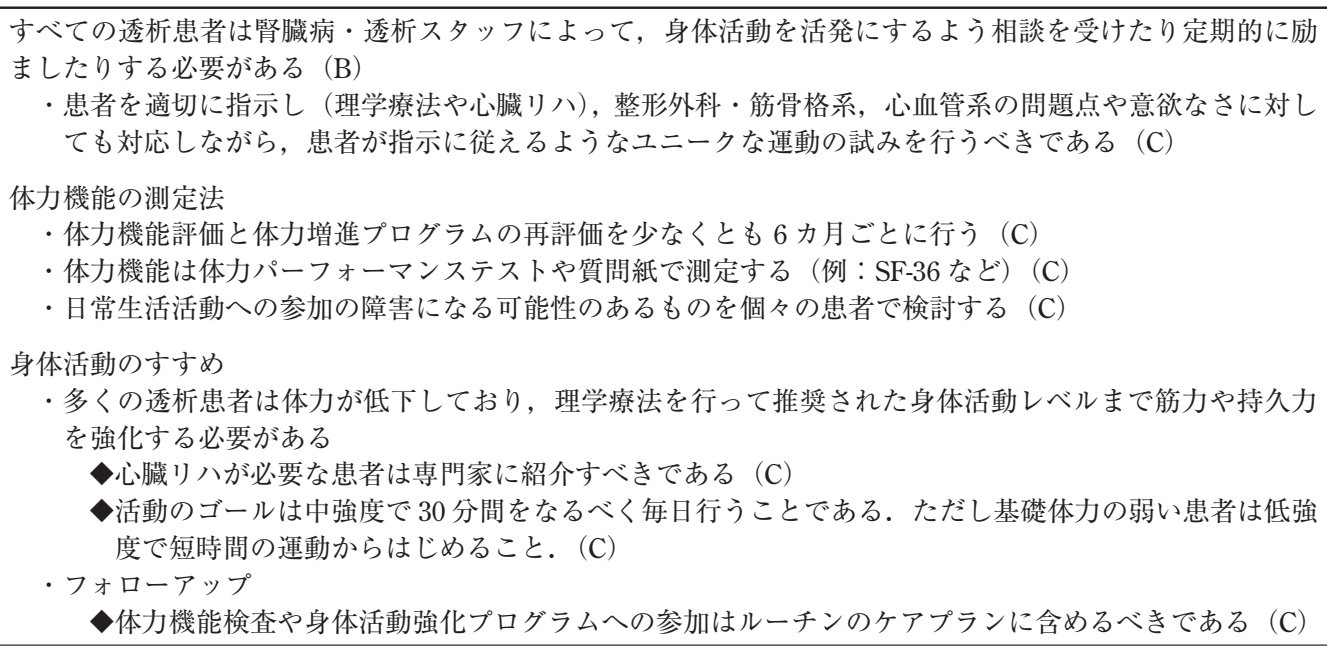

$\mathrm{A}$ ：行うよう強く勧められる， B：行うよう勧められる， C : 行うよう勧められるだけの根拠が明確でない, $\mathrm{D}$ : 行わないよう勧められる

表 6 腎不全透析患者に扮ける運動療法の効果（文献 24 より引用)

1 最大酸素摂取量の増加

2 左心室収縮能の克進 (安静時・運動時)

3 心蔵副交感神経系の活性化

4 心臓交感神経過緊張の改善

5 低栄養 - 炎症 - 動脈硬化 (MIA) 複合症候群の改善

6 貧血の改善

7 睡眠の質の改善

8 不安.うつ. QOL の改善

9 ADL の改善

10 前腕静脈サイズの増加（特に等張性運動による）

11 透析効率の改善

12 死亡率の低下

必要性や有効性に対する理解は十分でなかった。 また，科学的かつ合理的な運動療法メニューの開 発などの研究も必要である. 2011 年 1 月に腎臓 リハの一層の普及・発展を目的として，職種を超 えた学術団体である日本腎臓リハ学会を設立し た ${ }^{33)}$ 。た， 2012 年にわが国のみならず世界初 の腎臓リハの成書である「腎臓リハビリテーショ ン」を発刊した ${ }^{25)}$. 今後大きなテーマとなること は確実な腎臓リハの普及と発展に貢献し，多くの 腎臓機能障害者の福音となることを期待したい。

\section{肝臓機能疾患}

肝臓機能障害は 2010 年 4 月に新たに追加され ることになった新しい内部障害である ${ }^{34)}$. 肝蔵機 能障害の基礎疾患として, ウイルス性肝炎, 自己 免疫性肝炎, 原発性胆汁性肝硬変, アルコール性 肝障害, 非アルコール性脂肪性肝疾患（Nonalcoholic Fatty Liver Disease : NAFLD), 薬剤性肝疾 患等がある。

肝臟機能障害の身体障害認定基準は，ChildPugh 分類による評価を基本として, 補完的な肝 臓機能の検査数值, 病状に影響する病歴, 日常生 活活動に関する症状を総合的に勘案する。すなわ ち Child-Pugh 分類スコア 10 点以上の状態に一定 期間あって, 回復困難なものが相当する。身体障 害 (肝臓機能障害) の対象となる肝硬変患者は全 国で重度の肝臓機能障害患者約 $3 \sim 5$ 万人と肝臓 移植患者 5000 人程度と推定される ${ }^{34)}$.

肝臓機能障害患者の特徵と障害は, 脱力感, 掻 痒感, 筋肉痛, 体重減少, 腹水による腹部の膨満 感，浮腫，消化管の静脈瘤の破綻による吐下血， 脳症による意識障害・昏睡, 食思不振・悪心・嘔 吐などである。このような症状により $\mathrm{ADL}$ が制 
限される。

肝臓機能障害そのものに対する運動療法の効果 に関する基礎的, 臨床的な研究もこれまであまり 行われてこなかった，運動により肝血流量が一過 性に減少することから，急性や慢性にかかわらず 肝臓機能障害が認められると，まず安静を指示さ れてきた歴史的背景も影響していると考えられ る ${ }^{35)}$. 確かに, 現時点では肝炎や肝硬変への運動 療法が肝臓機能改善に有効であるとのエビデンス は確立していない。しかし，非代償期肝硬変や急 性肝炎の極期以外の病態では運動が肝臓障害を増 悪させたとするエビデンスもない.

一方，肝硬変患者では $\mathrm{ADL}$ や運動耐容能が低 下し, 運動耐容能の低い肝硬変患者は生命予後が 悪いことも明らかになった $(\text { 図 3 })^{36)}$ 。肝炎や肝硬 変の治療においても過度の安静によるディコン ディショニングの問題，社会復帰の遅延，QOL の低下も注目されている。すなわち，肝炎や肝硬 変の治療においても必要以上の安静を解除し, 社 会復帰に向けて少しずつ安全に運動の再開を図ろ うとする考えに変化してきている.

また，NAFLD P NASH では，生活習慣病であ る肥満, 2 型糖尿病, 高脂血症等がその発症の危 険因子であり，運動療法は食事療法と共に $\mathrm{NAFLD} \cdot \mathrm{NASH}$ 治療の基本となっている，さら に他障害に対するリ八目的の患者に肝疾患を併せ 持つ例も少なくなく, 肝臓障害時における運動療 法，食事療法，および日常生活指導に関する知識 は非常に要求されている.

以上のことから，肝臓機能障害患者において も, 運動療法は必要であり, 食事療法, 薬物療 法, 教育などとともに行われるべきであると考え られる。すなわち, 肝臓リハは他の内部障害リハ と同様，包括的リハとして運動療法，教育，食事 療法，精神的ケアなどを行う新たなリハ領域であ ると考えられる。

肝臓リハにおいては，その病態の特殊性を理解 したリハメニューの作成が重要である。例えば, 小児においても NAFLD・NASH が肝硬変まで進 展した症例も報告されている。筆者らは，肥満を 有する小児 NAFLD 症例に対して，食事療法，運

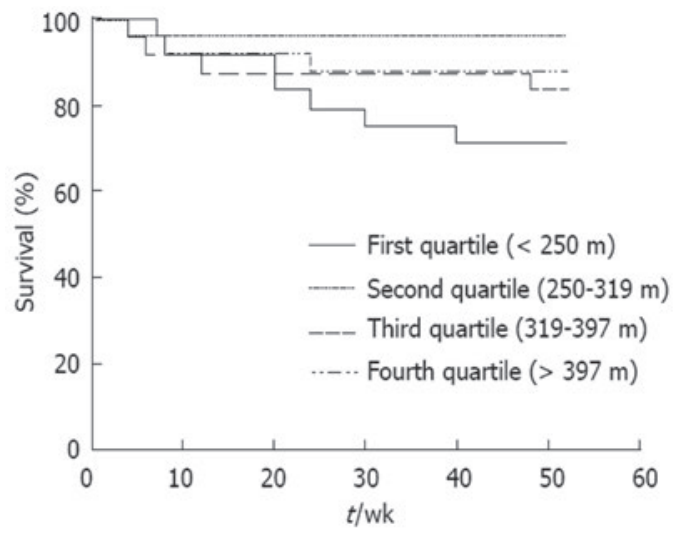

図 3 肝硬変患者の運動耐容能別 Kaplan-Meier 生 存曲線（文献 36 より引用）

6 分間歩行距離 $(\mathrm{m})$ で 4 分割して生存曲線を示した. $250 \mathrm{~m}$ 以上群に比較して $250 \mathrm{~m}$ 未満群は有意に生命予 後が悪かった $(p<0.05)$.

動療法や生活習慣是正教育をプログラム加えた入 院型包括的リハを実施し，1900 kcal という普通 給食（すなわち非常に軽度の食事制限）であって も，適切な運動療法を加味することで肝蔵逸脱酵 素值の著明な改善効果を認めている37). また，肝 肺症候群は，慢性肝疾患の患者にまれに認められ る重篤な合併症であるが，換気血流不均等が基礎 に存在し，起立性の換気血流不均衡による酸素化 障害を認め, 酸素療法に対しての反応も悪く，ま た肝臓移植後でも低酸素血症の改善が遅延するこ とが多く，リハに難渋することが多い．筆者ら は，本症候群の特徵を考慮し，仰臥位で上下肢の 可動域訓練や運動を行い, 安全かつ著明な改善を みた ${ }^{38,39)}$.さらに，肝臟移植後患者では 1 回 30 分以上, 週 3 回の運動を行っている群で QOL が 高いという報告がある ${ }^{40)}$ 。特に QOL の physical functioning scale や physical component scale には 運動療法に参加することが年齢，他の併存疾患数 などとは独立した寄与因子となっている ${ }^{41}$.

このように, 肝臓機能障害患者の包括的リハ は，生活機能や QOL 改善のみならず，治療や生 命予後改善としての意味合いも期待され, 今後の 一層の発展が期待される ${ }^{35)}$. 


\section{おわりに}

国内外の動向や教室の最新の成績をまじえなが ら，このような内部障害リハの理論と実際を論じ た.内部障害リハは, 単に $\mathrm{ADL}$ を拡大し在宅, 復職を目指すことが最終目標とするリハではな く, 動脈硬化性疾患の発症・再発予防, 生命予後 の延長などにもつながる「極めて有効な治療」の 1つである.内部障害リ八は生活の質の改善と寿 命の延長（adding life to years and years to life）を 達成できる医療であり, 内部障害リハは医療の王 道として今後ますます重要な分野となると考えら れる。

内部障害患者の高齢化が進んでいる．このよう な患者では重複障害や認知障害を合併しているこ とが多く，それを理由に内部障害リハに加われな い場合も少なくないとされている ${ }^{42}$.むしろ，内 部障害リハ患者の高齢・障害の重複化に対して は，関節拘縮・バランス改善や予防という理学療 法や環境対策も含めた広い意味でのリハに熟知し たリハ科医・リハ関連職種がこれまで以上に積極 的に参画することが望まれる。

\section{文献}

1）上月正博: オーバービュー: "adding life to years” から "adding life to years and years to life" $に$. J Clin Rehabil $2012 ; 21: 436-444$

2) Kohzuki M : Paradigm shift in rehabiulitation : from "adding life to years" to "adding life to years and years to life". Asian J Health Science $2012 ; 2: 1$-8

3) 上月正博 編: 新編 内部障害のリハビリテーション. 医歯薬出版, 東京, 2011

4）厚生労働省ホームページ : Available from URL : http:// www.mhlw.go.jp/toukei/saikin/hw/shintai/06/dl/01. pdf (cited 2013 January 31)

5）上月正博: 変わるリハビリ〜攻めのリハビリと拡大す る対象疾患〜. ヴァンメディカル社, 東京, 2006

6) Wenger NK, Froelicher ES, Smith LK, et al : Clinical Practice Guideline No 17. in Cardiac Rehabilitation. AHCPR Publication No. 96-0672, 1995 ; pp1-26

7) 循環器病の診断と治療に関するガイドライン 2006 年 度合同研究班報告. 心血管疾患におけるリハビリテー ションに関するガイドライン (2007 年改訂版). Available from URL : http://www.j-circ.or.jp/guideline/pdf/ JCS 2007_nohara_h.pdf (cited 2013 January 31)

8) American College of Cardiology ; American Heart Asso- ciation Task Force on Practice Guidelines ; Canadian Cardiovascular Society : ACC/AHA guidelines for the management of patients with ST-elevation myocardial infarction : a report of the American College of Cardiology/ American Heart Association Task Force on Practice Guidelines. Circulation 2004 ; 110 : e 82-292

9）厚生労働省保険局医療課: 平成 22 年度診療報酬改定関 連通知 : Available from URL : http://www.mhlw.go.jp/ bunya/iryouhoken/iryouhoken12/setumei.html (cited 2013 January 31)

10）上月正博：わが国における心臓リハビリテーションの 実態と普及促進の課題. 呼吸と循環 $2011 ; 59: 275-282$

11）上月正博：内科疾患の運動療法とリハビリテーション 一国内外の動向. 総合リハビリテーション $2011 ; 39$ : 521-527

12) Ries AL, Bauldoff GS, Carlin BW, Casaburi R, Emery CF, Mahler DA, Make B, Rochester CL, Zuwallack R, Herrerias $\mathrm{C}$ : Pulmonary rehabilitation : Joint ACCP/AACVPR evidence-based clinical practice guidelines Chest 2007 ; $131: 4 \mathrm{~S}-42 \mathrm{~S}$

13) National Heart, Lung and Blood Institute, World Health Organization : Global initiative for chronic obstructive lung disease (GOLD) workshop summary. Global strategy for the Diagnosis, Management, and Prevention of Chronic Obstructive Pulmonary Disease. Available from URL : http://www.goldcopd.com/Guidelineitem.asp?11 $=2 \& 12=1 \&$ intId $=989($ cited 2013 January 31$)$

14) 日本呼吸器学会COPDガイドライン第 3 版作成委員会 編 : COPD診断と治療のためのガイドライン第 3 版. メ ディカルレビュー社, 東京, 2009

15）日本呼吸管理学会呼吸リハビリテーション作成委員会, 日本呼吸器学会ガイドライン施行管理委員会, 日本リ ハビリテーション医学会呼吸リハビリテーションガイ ドライン策定委員会, 日本理学療法士協会呼吸リハビ リテーションガイドライン作成委員会 : 呼吸リハビリ テーションマニュアル—運動療法一第 2 版. 昭林社, 東 京, 2012

16）日本呼吸管理学会呼吸リハビリテーション作成委員会, 日本呼吸器学会ガイドライン施行管理委員会, 日本リ ハビリテーション医学会呼吸リハビリテーションガイ ドライン作成委員会, 日本理学療法士協会呼吸リハビ リテーションガイドライン作成委員会 : 呼吸リハビリ テーションマニュアル一患者教育の考え方と実践一. 昭林社, 東京, 2007

17）上月正博：運動療法は高齢心肺機能障害者のフィジカ ルフィットネスの改善に寄与するか. リハビリテー ション医学 $2004 ; 41: 393-397$

18) Kohzuki M, Kurosawa H, Goto Y, Hida W, Ohishi J, Mori N, Nagasaka M, Ito O, Minami N, Kanazawa M : Pulmonary rehabilitation survey in the north Japan : recommendation and participation. Am J Respir Crit Care Med $2006 ; 171$ : A 814

19）社団法人日本透析医学会ホームページ 図説 わが国 の慢性透析療法の現況. Available from URL : http:// docs.jsdt.or.jp/overview/index.html (cited 2013 January 31)

20) Painter P : Physical functioning in end-stage renal dis- 
ease patients : Update 2005. Hemodial Int 2005 ; 9 : 218 235

21) O'Hare AM, Tawney K, Bacchetti P, Johansen KL : Decreased survival among sedentary patients undergoing dialysis : results from the dialysis morbidity and mortality study wave 2 . Am J Kidney Dis 2003 ; 41 : 447-454

22) Tentori F, Elder SJ, Thumma J, Pisoni RL, Bommer J, Fissell RB, Fukuhara S, Jadoul M, Keen ML, Saran R, Ramirez SP, Robinson BM : Physical exercise among participants in the Dialysis Outcomes and Practice Pat terns Study (DOPPS) : correlates and associated outcomes. Nephrol Dial Transplant $2010 ; 25$ : 3050-3062

23）上月正博: 腎臓リハビリテーションとは何か. 臨床栄養 $2011 ; 118: 334-335$

24) NKF-K/DOGI : K/DOQI Clinical Practice Guidelines for Cardiovascular Disease in Dialysis Patients. Am J Kid Dis 2005; 45 (Suppl 3) : S 1-S 128 (塚本雄介訳: K/ DOQI透析患者における心血管病CVDガイドライン. Available from URL: http://www.jinzou.net/ (cited 2013 January 31)

25）上月正博 編著 : 腎臓リハビリテーション. 医歯薬出版, 東京, 2012

26）エビデンスに基づくCKD診療ガイドライン（日本腎臓 学会 編). Available from URL: http://www.jsn.or.jp/ckd/ ckd2009_764.php (cited 2013 January 31)

27) Kohzuki M, Kamimoto M, Wu XM, Xu HL, Kawamura T, Mori N, Nagasaka M, Kurosawa H, Minami N, Kanazawa M, Saito T, Yoshida K : Renal protective effects of chronic exercise and antihypertensive therapy in hypertensive rats with chronic renal failure. J Hypertens 2001 ; $19: 1877-1882$

28) Kanazawa M, Kawamura T, Li L, Sasaki Y, Matsumoto K, Kataoka H, Ito O, Minami N, Sato T, Ootaka T, Kohzuki $\mathrm{M}$ : Combination of exercise and enalapril enhances renoprotective and peripheral effects in rats with renal ablation. Am J Hypertens $2006 ; 19$ : 80-86

29) Lu H, Kanazawa M, Ishida A, Tufescu A, Sasaki Y, Ito O, Kurosawa H, Sato T, Ootaka T, Kohzuki M : Combination of chronic exercise and antihypertensive therapy enhances renoprotective effects in rats with renal ablation. Am J Hypertens 2009 ; 22 : 1101-1106

30) Tufescu A, Kanazawa M, Ishida A, Tufescu A, Sasaki Y, Ito O, Kurosawa H, Sato T, Ootaka T, Kohzuki M : Combination of exercise and losartan enhances renoprotective and peripheral effects in spontaneously type 2 diabetes mellitus rats with nephropathy. J Hypertens 2008 ; 26 : $312-321$
31) Kohzuki M, Wu X-M, Sato T, Kawamura T, Yoshida K, Mori N, Nagasaka M, Harada T, Ito O, Minami N, Kurosawa $\mathrm{H}$, Kanazawa M : Disability prevention of renal failure : effects of exercise and enalapril in Thy -1 nephritis rats. Proceedings of the 2nd World Congress of the International Society of Physical and Rehabilitation Medicine, Monduzzi Editore, Bologna, 2003 ; 521-524

32) Kohzuki M : Renal Rehabilitation : present and future perspecives. in Hemodialysis (ed by Suzuki H). Pfiper Inc., New York, 2013 (in press)

33）日本腎臓リハビリテーション学会ホームページ : Available from URL : http://jsrr.jimdo.com/ (cited 2013 January 31$)$

34）厚生労働省身体障害認定等に係る担当者会議次第： Available from URL : http://www.wam.go.jp/wamappl/ bb15GS60- nsf/0/1aaa40236b8c5436492576340028ce4a/ \$FILE/20090917_1shiryou_all. pdf (cited 2013 January 31)

35）上月正博 : 肝臓機能障害患者における障害とリハビリ テーションの考え方. J Clin Rehabil 2011；20 : 312-321

36) Alameri HF, Sanai FM, Al Dukhayil M, Azzam NA, AlSwat KA, Hersi AS, Abdo AA : Six minutes walk test to assess functional capacity in chronic liver disease patients. World J Gastroentero 2007 ; 13 : 3996-4001

37）伊藤 修, 室谷嘉一, 坂田佳子, 森 信芳, 長坂 誠, 金 澤雅之, 藤原幾磨, 上月正博 : 小児非アルコール性脂肪 性肝疾患 (NAFLD) への運動療法の効果. 運動療法と 物理療法 $2009 ; 20: 82-87$

38）上月正博, 阿保孝文, 渡辺美穂子, 後藤葉子, 大河内信弘, 里見 進, 佐藤徳太郎: 生体肝移植を行った肝肺症候群 患者に対するリハビリテーション.リハビリテーショ ン医学 1999 ; 36 : 655-657

39) Kohzuki M, Abo T, Watanabe M, Goto Y, Ohkohchi N, Satomi S, Sato T : Rehabilitating patients with hepatopulmonary syndrome using living-related orthotopic liver transplant : a case report. Arch Phys Med Rehabil 2000 ; $81: 1527-1530$

40) Painter P, Luetkemeier MJ, Moore GE, Dibble SL, Green GA, Myll JO, Carlson LL : Health related fitness and quality of life in organ transplant recipients. Transplantation 1997 ; 64 : 1795-1800

41) Painter P, Krasnoff J, Paul SM, Ascher NL : Physical activity and health-related quality of life in liver transplant recipients. Liver Transpl $2001 ; 7$ : 213-219

42）上月正博 : 運動療法でのポイント.J Clin Rehabil 2009; $18: 301-308$ 